\title{
Postmodernism and the Ontological Dominant: The Poetics of Integration in Peter Ackroyd's The House of Doctor Dee
}

\begin{abstract}
This article proposes an analysis of Peter Ackroyd's The House of Doctor Dee (1993) in the light of two different dichotomies: Brian McHale's epistemological (cognitive) / ontological (postcognitive) dominant and John Vernon's garden / map dynamics. The House of Doctor Dee is constructed around a series of strategies closely related to the postcognitive worldview, strategies which have come to be associated with postmodernist aesthetics and which can as well be regarded as confirming and developing ideas and devices already present in previous works by the same author. Significantly, the techniques in what McHale calls the postmodernist repertoire can be said to be based on the same integrative principle that rules Vernon's garden, the latter being an image of wholeness which stands in direct opposition to the splitting rationale of the map. Vernon's dynamics of integration, together with McHale's ontological structures, become in my analysis the key to understanding Ackroyd's novel, while simultaneously suggesting an interesting perspective from which to approach postmodernist literature as a whole.
\end{abstract}

For about two decades now, "postmodernism" has been a key word in the vocabularies of not only literary theorists but also political scientists, philosophers, artists, media theorists, sociologists, etc. ${ }^{1}$ Almost twenty years ago, though, the American critic and writer John Barth (1966: 66) declared it to be a term "awkward and faintly epigonic, suggestive less of a vigorous or even interesting new direction in the old art of storytelling than something anticlimactic, feebly following a very hard act to follow". In 1980, the term was beginning to enter the full range of human sciences, and still carried clear aesthetic connotations. 
Thus, for Barth, postmodernism is a continuation but modification of cultural modernism, a way of "telling stories". Though by now postmodernism as a concept has spilled out of the boundaries of literary critical debate, it still carries with it, as Patricia Waugh (1992: 1) points out, this idea of telling stories, but stories that have become indistinguishable from what was once assumed to be knowledge (scientific "truth", ethics, law, history...). Postmodernism, Waugh adds, has also invented its own genealogy or, rather, it has constructed genealogies. Accordingly, just as there is a variety of theoretical precursors and historical trajectories so there are many postmodernisms.

In his quest for an all-encompassing theory of postmodernism, Brian McHale discusses several approaches to the subject by critics as well-known as Jean Franłois Lyotard, Richard Rorty, Hayden White, Christopher Norris, Gerald Graff, David Lodge, Christine Brooke-Rose and John Barth, among others. Significantly, their respective accounts of postmodernism appear in McHale's analysis as "postmodernist stories" (1992: 19-37), a phrase he uses in an attempt to trivialize the more serious connotations of the term "theory".

In this light, it does not come as a surprise when McHale refers to his version of the myth of the postmodernist breakthrough as "my own story" $(1992: 32-33 ; 272)$ or when he presents it as deriving from a work by Dick Higgins (1978)-poet, composer, performance artist, and sometime small-press publisher- which is fashioned in the form of a tale, that is, as another story.

McHale devises his well-known proposal by extrapolating Higgins' distinction between cognitivism and postcognitivism (1978: 101) to a field-literary fiction-that Higgins does not take into consideration (at least explicitly). Thus, $\mathrm{McH}$ ale suggests that postmodernist literature foregrounds its ontological structure as opposed to modernist literature, which is based on an epistemological dominant. Modernist literature is centred around the pursuit of knowledge, asking (cognitive) questions such as: "How can I interpret this world of which I am a part? And what am I in it?' Postmodernist works, on the other hand, foreground the plurality of ontologically distinct worlds as they elicit (postcognitive) questions such as: "Which world is this? What is there to be done in it? Which of my selves is to do it?' (McHale 1992: 32-34, 146-47, and passim; see also 1987: xii, 3-25, and passim).

The novel I intend to analyse here-Peter Ackroyd's The House of Doctor Dee (1993)-should be placed on the postcognitive/postmodernist side of the line, as it is constructed around a series of strategies closely related to the postcognitive worldview, strategies which have come to be associated with postmodernist aesthetics, and which can as well be regarded as confirming and developing ideas and devices already present in previous works by the same author. This is not to say, however, that there is no place in the novel for what Higgins first and McHale later call "cognitive questions". As McHale's terminology suggests, the matter we face has to do with "dominants", that is, groups of features which are not the only thing there is in a work but which are given relevance over something else, thus setting the tone of the novel we happen to be reading and leading our interpretation along certain paths.

Accordingly, in the first part of this paper, I will analyse the process by which the ontological dominant takes over the epistemological one in The House of Doctor Dee. In 
the novel's context, the distinction epistemological-ontological can be further explained in the light of what John Vernon (1973) calls "structures of splitting" and "structures of wholeness". Thus, in the second part of my study ${ }^{2}$, the main characters' trajectory in their respective quests for knowledge is presented as an evolution from separation to integration. Moreover, wholeness, as opposed to splitting, is not only the outcome of the protagonists' process of learning but also the principle at the core of Ackroyd's novel. And, to a great extent, isn't it also the principle on which postmodernist literature can be said to be based?

The House of Doctor Dee begins with the contemporary narrator-character, Matthew Palmer, moving to an old house which he has just inherited from his recently deceased father. As he soon learns, the house in Clerkenwell did once belong to one of the most famous magicians in the time of Elizabeth I-Dr John Dee.

The second chapter, which is not "Two" but "The Spectacle", turns out to be narrated by Dr Dee himself and, accordingly, the events recounted there are set in the narrator's lifetime - the sixteenth century. Moreover, the novel's structure is based on this alternation between different narrative voices and chronological periods, as happens in Hawksmoor (1985) and Chatterton (1987). Matthew's chapters are set in 1993 and are numbered -from "One" to "Seven"- while Dr Dee's take place in Renaissance England and present chapter-headings related to the events told in each section. The novel closes with "The Vision", an all-inclusive chapter which could be defined as a combination of historical periods, plot lines and narrative voices -Matthew's, Dr Dee's, and even Peter Ackroyd's.

The first chapters of the novel are enough for us to approach its main characters' quests for knowledge in the light of the epistemological dominant. The epistemological dominant usually gives raise to novels that resemble detective fiction - the epistemological genre par excellence - in the sense that their plots take the form of a quest for a missing or hidden item of knowledge. The protagonist is a "cognitive hero" and the story revolves around problems related to the accessibility and circulation of knowledge, the individual mind's grappling with an elusive or occluded reality (McHale 1992: 147).

Both Matthew Palmer and John Dee are cognitive heroes. Matthew himself is a professional researcher, and so is his close friend Daniel Moore. At the time the novel opens, Matthew is carrying out a piece of research on Elizabethan costume for a theatrical company ${ }^{3}$, which, once again, has sent him backwards to the past. Significantly enough, his job, he explains, has led him to view the past in general as his own present, while he has in turn come to perceive the present moment as part of the past (HD 13). The discovery that the place his father has left him was owned by such an intriguing figure as Dr Dee, together with the uncanny atmosphere of the house itself, awakes in him a growing desire to know more details about John Dee, who becomes, from that moment on, Matthew's private obsession, and the main object of his quest.

A strong desire to recuperate the past leads not only Matthew's but also Dee's activities as described in the sections narrated by each of them. If, for Matthew, the past is Dr Dee's life and work, for Dee it has to do with the (re-)discovery of the lost city of London, a mystical place founded by the mythical forefathers of the English race - godlike men, giants of spiritual power, who inhabited the earth before the Flood (HD 190). The possibility of having access to their records and controlling their spiritual power haunts $\mathrm{Dr}$ Dee as that would provide him with the key to the essence of things and people or, what 
is the same, the key to mint gold and create life without the help of any womb (HD 77, 104).

Having explained the premises under which Matthew's and Dr Dee's respective quests begin, we could now ask ourselves whether the outcome corresponds to the questers' initial objectives.

In his postscript to The Name of the Rose, Umberto Eco (1984: 54) describes his novel as "a mystery in which very little is discovered and the detective is defeated". Although, to a great extent, William of Baskerville can be said to discover the truth, he does so not by logical deduction - as a successful detective would have done- but, rather, by mere chance:

"There was no plot", William said, "and I discovered it by mistake. . . I arrived at Jorge through an apocalyptic pattern that seemed to underlie all the crimes; and yet it was accidental. I arrived at Jorge seeking one criminal for all the crimes and we discovered that each crime was committed by a different person, or by no one. I arrived at Jorge pursuing the plan of a perverse and rational mind, and there was no plan, or, rather, Jorge himself was overcome by his own initial design and there began a sequence of causes, and concauses, and of causes contradicting one another, which proceeded on their own, creating relations that did not stem from any plan. Where is all my wisdom, then? (1983: 492)

Similarly, both Matthew and Dr Dee discover a truth about themselves and about the world, but they do so accidentally, by pursuing the wrong goals and then recognizing their mistakes. As their quests gradually change their respective foci, the novel's epistemological component is invaded by something else. What rushes in is in fact ontological structure and thematics, or, in other words, McHale's postmodernist poetics. This is not to say, I insist, that the story is evacuated of its epistemological questions but, simply, that other questions are foregrounded to the point that the reader him/herself comes to partake in the kind of dynamics they posit ${ }^{4}$.

In this light, The House of Doctor Dee can be said to draw on several of the strategies which McHale includes in what he calls the "postmodernist repertoire", and which are therefore related to the ontological dominant of "What world is this?...". He groups them into two categories: firstly, strategies that stage confrontations among two or more worlds, thus focusing attention on the boundary or interface between them; and, secondly, strategies that destabilize the projected world of the novel itself, thus foregrounding the very process of world construction (McHale 1992: 151-52). I will follow this classification in order to analyse the way in which postmodernist devices are used in Ackroyd's work.

The most conspicuous ontological confrontation in The House of Doctor Dee is the one between the novel's fictional world and real-world historical fact. In this respect, The House of Doctor Dee may be said to repeat the pattern of Ackroyd's previous novels as well as that of all the works included in what Linda Hutcheon first called "historiographic metafiction", a phrase meant to designate "those well-known and popular novels which are both intensively self-reflective and yet paradoxically also lay claim to historical events and personages" (Hutcheon 1988: 5). As Hutcheon further explains, the incorporation of 
historical events in this kind of novel is by no means innocent. In fact, historiographic metafiction plays upon the truth/lie opposition with regard to historical records as it acknowledges "the paradox of the reality of the past but its textualized accessibility to us today" (Hutcheon 1984: 114, italics in the original).

It is on account of the fact that books constitute the only possible access to the past that Dr Dee praises his library as one of the most precious things in his kingdom (HD 63). Living among books, as he (and Matthew himself) does, is like living within the past. But living within the past in this manner, that is, understanding past ages, becomes in turn the only way to master the present (HD 67). This comes close to what Matthew feels when working with "old books and old papers", a task which throws light upon both himself and the immediate world around him (HD 13).

It is through a particular text - "a thick old book ... printed anno 1517"- that Dr Dee has learnt about and come to believe in the lost city of London. Though he has no doubt as to its existence, it is only in the book that he finds it, and not even there, as, according to Dee's narration, the work in question was stolen, taken from him when he was imprisoned by Queen Mary's order on the charge of being a conjuror (HD 66).

Similarly, though the house to which he has just moved constitutes Matthew's main "door" to the Renaissance owner of the place, it is in the English History Library that he tries to "find John Dee" (HD 129). But to no effect. The only conclusion he reaches after his thorough research of the library's records is that "the past is difficult", not to say ungraspable. As he explains to Daniel, every book he has read has a different Dr Dee and none of them are alike (HD 136). Accordingly, Ackroyd's is just one more version of the complex controversial figure that Dr John Dee once was, and for us still is.

The presence of real-world historical personages in a fictional text -Dr Dee, but also his wife, Edward Kelly, or, for that matter, Peter Ackroyd himself, whose voice we hear in the last chapter - is a case of what Eco (1979: 229) has called "transworld identity". Transworld identity is always a sign of the penetration of one world by another, the violation or, rather, the blurring of an ontological boundary. In The House of Doctor Dee, as is the case with countless other historiographic metafictions, this is the boundary between reality and fiction but also, partly as a consequence, the boundary that separates characters and chronological periods. I will explain this point further in what follows.

After reading the first chapters of the book, the reader has enough data to distinguish the two narrative voices-one is Matthew's, the other, Dr Dee's- as s/he is explicitly informed about the time in which the events narrated take place and, above all, on account of the fact that each narrator uses his own idiolect. Moreover, Matthew speaks contemporary English, while Dr Dee speaks early Modern English. Inserted within Matthew's narrative are the documents he finds in the house, produced by people living there at different ages (from the seventeenth century onwards) and so, written in "several different hands and scrawled across various types of paper" (HD 219). Likewise, Dr Dee's sections are "contaminated" with the Latin of his studies as a medievalist, as well as with the popular, lower-class speech of several characters - John Overbury (Dee's old assistant in "The Hospital"), Edward Kelly, Dee's servants, etc.- and of the numerous rhymes inserted throughout these sections, not to mention the "canting" dialect of the vagrant 
(Philip Jennings) who unexpectedly appears in Dee's garden and speaks in "some ancient tongue of the country" unknown to Dee (HD 70).

As Mikhail Bakhtin or Michel Foucault would put it, different languages, different registers of the same language construct the world differently or, in other words, they each construct different worlds. However, as happens with the distinction between fact and fiction, all these worlds become one in the novel. Thus, Dr Dee's scryer is able to listen to pieces of conversation between Daniel and Matthew, just as the latter perceives distinctly some of the words uttered by Dee and Edward Kelly, and even answers to what he thinks is a person standing behind him when he is looking at Dee's crystal globe in the British museum (HD 248).

If words/language share this transworld identity, the same happens with the characters' lives. The experiences a person goes through constitute that person's life, and they anchor him/her to a particular period in time, as well. By contrast, what we find in the novel is that the same events are shared by different people living in different ages. This goes beyond the fact that Matthew and Dee have striking biographical traits in common-they are both self-centred, solitary, and even unsociable men, in love with books and the past, in bad terms with their respective fathers, etc. Thus, just as John Dee succumbs to the charms of a whore -Marion - the day when his father dies (HD 120), Matthew hires a prostitute-Mary - shortly after his father's death (HD 173). Moreover, Dee is somehow allowed to see them as Matthew defiles her in the house basement (HD 217), which is in turn the very same place where Daniel and Matthew's father performed their sexual rituals (HD 172). Likewise, if on page 136 Matthew breaks a pigeon's wing (by throwing at it a book on the life and works of Dr Dee) and furiously beats it until it dies, the (same?) dead pigeon with "a single wing" appears some pages later in the mouth of Dee's cat (HD 159). Many other things recur throughout the two narrators' accounts. The tune "Fortune, My Foe" is first sung by Dee, on a night walk at the end of the second chapter, and then by the vagrant in Dee's garden (HD 71). Later on, Matthew finds himself repeating the words of a song he had heard that morning as he sat in the old house, a song which, to his best knowledge, is called "Fortune, My Foe" (HD 142). Among the documents that Matthew's father had preserved, he finds the story of an early twentieth-century writer tormented by the fear that everything he writes are plots and words stolen from some other source. He seems to have lived in Dee's house as well, where he has just finished a book on the strikes and riots in eighteenth-century London, a book which turns out to have already been written by someone else (HD 222-24). Significantly, Daniel Moore is also writing a book on a subject related to London radicalism. Whether or not it is the same book, or whether the former is or is not included in the latter, the topic (the "anxiety of influence", the impossibility of being original, etc.) recalls other versions of it in Ackroyd's works to the point that, after so many coincidences, the reader is tempted to say with Dr Dee that "One and One is all alone, and even more shall be so" (HD 103). Everywhere we look, what we had initially perceived as separation, tension or confrontation dissolves in a pervading (transworld) unity. One is all and all is one.

In sum, there are several worlds, but they are all the same. Further considerations can be added to this conclusion, considerations that are related to the second group of strategies in McHale's "postmodernist repertoire". The above-mentioned world, which is 
many -Dr Dee's and Matthew's, past and present, history and story-but is one, is no other than the world of the novel, which self-consciously calls attention to its own fictional status.

"Writing a novel", Eco tells us, "is a cosmological matter, like the story told by Genesis" (Eco 1984: 20). The "cosmos" of The House of Doctor Dee has its own demiurge, who is Peter Ackroyd. As could be expected from a postmodernist novel, the position he occupies is far from being that of an author who keeps himself aloof from his work, "paring his fingernails". Ackroyd is behind his novel and, what is more, he is also within it. Just as Dee makes his the Hermetic principle that "What is above also lies below, what is below is also above" (HD 77), so Ackroyd illustrates in The House of Doctor Dee the postmodernist conviction that the way in, so to say, is the way out: as reality is levelled with fiction, there is no breach between the real world and the world of the novel. No wonder, then, that its author is both without and within it.

It is in the last chapter of The House of Doctor Dee that the author joins his characters. It is also there that he acknowledges his difficulties to separate what there is of history from what there is of invention in the pages we have just read. However, he also reveals himself as a craftsman, a world-maker: "Just as he [John Dee] took a number of mechanical parts and out of them constructed a beetle that could fly [in "The Spectacle"], so I have taken a number of obscure texts and have fashioned a novel from their rearrangement" (HD 275). Such a statement calls attention to the author's three main facets: as researcher, as imaginative creator, and last but not least, as deviser of patterns.

In addition to being inseparable from the novel's content, its form has been contrived in such a way that it reinforces the work's main themes while simultaneously foregrounding its fictional nature. Interestingly enough, just as the lives of Dr Dee and Matthew seem to criss-cross and coincide at several points, the chapters they narrate are not simply juxtaposed but carefully concatenated. Thus, the closing sentence of each chapter reappears at the beginning of the next one (until "Five"), or, alternatively (from "Five" to "Seven"), two chapters later. Different in status, the last section--"The Vision"- breaks the chain and stands apart from the rest.

Among the elements and techniques that may contribute to flaunting a novel's fictional quality, McHale (1992: 155) pays special attention to mirror reflections and mise-enabyme structures. In The House of Doctor Dee, the house where most of the action takes place conspicuously synthesizes all the novel is. As Matthew first sees the house building he concludes that it must have been rebuilt or restored in several different periods. In fact, he is able to distinguish older and younger parts just as the reader can perceive the alternation in the novel between chapters set in the far past of the sixteenth century from others set in the nearer past of 1993. As has been pointed out, though, both characters and events somehow break temporal boundaries, creating, rather, a feeling of atemporality. In the same way, the house, which belongs to different ages, is actually "not of any one period" (HD 2), as if all temporal dimensions had flown into it and lingered there waiting for every successive inhabitant (HD 82). Past, present and future meet within the walls of its three-level structure. Likewise, the reader of the novel can follow Matthew moving backwards in time to find Dr Dee, while the latter seems to be moving forwards, towards Matthew's present (which he sees in a vision). Matthew's present is Dee's future; Dee's 
present is Matthew's past; and they are all the reader's present as s/he meets every temporal dimension simultaneously in the act of reading. All times, then, meet in the house, and in the book.

When talking to Daniel about his initial (bibliographical) research on John Dee, Matthew utters some words that may have a curious effect on the reader: "I held up the book with the portrait of Dr Dee on its cover. 'Reader', I said, 'this is the beginning and the end"' (HD 137). The book Matthew refers to strangely resembles The House of Doctor Dee, which also has a portrait of Dr Dee on the cover. Once this connection is established, the words which follow may lead us to consider that it is the book we have in our hands that is "the beginning and the end", which points to circular temporality (cf. "The Vision") but also to world-inclusiveness in the sense that there is a world within the novel's first and last pages, and that that world - a fictional world which can no longer be opposed to a "real" one- is all there is.

According to Dee's theories, each material thing contains the world within it, it is "the visible home of universal power or congregation of powers" (HD 133). Moreover, man is a miniature replica of the world, a microcosm: "all [is] within us ... what exists in heaven and earth exists also within the human frame" (HD 58). Significantly, as Matthew points out, the house "resembled the torso of a man rearing up, while his arms still lay spread upon the ground on either side" (HD 3). If we add to this the fact that, as the Behmenists believed, and according to Daniel's explanation, "the universe itself [has] the shape of a single person" (HD 45), what we have is a sort of House/World/Book all at once.

To a great extent, architecture is the art "that most boldly tries to reproduce in its rhythm the order of the universe which the ancients called 'kosmos'" (Eco 1983: 26). Dr Dee's house no doubt reproduces the kind of universe his sixteenth-century owner believed in and which now becomes Matthew's, as it once was that of its other inhabitants (members, in this sense, of the same "spiritual family"). This doubling of the world of The House of Doctor Dee by the world-within-the world which is the house of Dr Dee opens up a kind of abyss of potentially infinite regress which becomes particularly conspicuous when Dr Dee himself has a vision of someone "writing upon a theme concerning me and my books" and is eventually able to "see" a thick volume "which had on its first page my house as its title in great letters" (HD 71). This volume en abyme, being the very same book we are reading, would repeat the process thus laying bare the complexity of the novel's ontological structure:

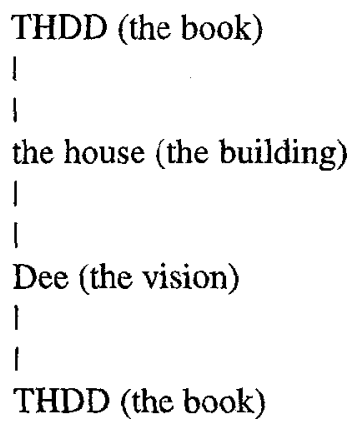


According to what we said at the beginning, the epistemological quests of both Dee and Matthew raise a series of postcognitive, rather than cognitive questions, which ultimately present the novel as a work written under the ontological (postmodernist) dominant. The final irony of all this process is that it is precisely by altering their initial tracks that Matthew and Dee succeed in the end. Moreover, their change of goals coincides with the introduction in the novel of thematical and formal strategies in the light of which the reader should interpret the work s/he is reading.

As has been pointed out, McHale (1992: 146-47) uses the opposition epistemological (cognitive) - ontological (postcognitive) to characterize the modernist and postmodernist dominants. Leaving aside the controversial issue of the relationship between modernism and postmodernism, I would now like to approach this opposition from the point of view of what John Vernon (1973) has called "structures of splitting" and "structures of wholeness", which he explicitly associates with two images particularly suitable in the context of Ackroyd's work - the map and the garden - and which I have related in turn to the way in which the two main characters evolve as the novel goes on.

Vernon's garden is first and foremost the Garden of Eden, where Adam and Eve lived in a proximate and fluid environment. There is an aspect of wholeness to this life, a naive direct participation of all forms of life in each other, a synthetic function to all experience. The garden represents, then, the principle of unity and integration, while the map stands for separation, the principle of either-or, here and there, now and then, subject and object, etc.

The best symbol of the garden is the Tree of Life. Without having a concrete location, the Tree reenacts the whole cosmos and the very rhythm of life; its organization is growth itself, the fluid unity of part and whole, by which every part manifests the whole (Vernon 1973: 6). As to the map, its main symbol is the Tree of Knowledge. Formal knowledge relies on formal logic, whose dual system is the antithesis of the integrative organization of part and whole that existed in the Garden. Knowledge is not simply of Good and Evil, but of their separation, their polarity. The Tree of Knowledge, which propels Adam and Eve out of the Garden is, above all, then, the mechanical tree of discreteness and separation. And the Fall is in particular a fall into economic relationships: with it, objects outside the body become objects of desire and consumption, commodities, things that exist to be wanted; and the body becomes such an object as well (Vernon 1973: 10-12).

It is in this sort of fallen state that we initially find Dr Dee and Matthew. Dee's search for knowledge is first and foremost a search for gold, both the gold that he believes to have been hidden by his unloved and neglected father, and the gold he himself will be able to mint once he finds out the alchemical method. This ambition looms behind the journeys Dee describes in "The Library", a chapter which, significantly, begins with Dee contemplating "a map of the entire world ... theatrum orbis terrarum" (HD 50), and which also recounts Dee's visit to [what is left of] the tree beside which Faustus was taken away by the Devil. This version of the Tree of Knowledge, specifically associated with Satan, awakes in him the desire to "know everything..., to understand everything" (HD 55). Thus, he will follow the path of ambition, lovelessness and separation until his redemption comes. 
Matthew suffers from a similar spiritual barrenness. Feeling repulsion for his father and indifference for his mother, and worried only about himself, he explicitly describes his world as a world without love, a world of money and possession. This is the only thing he has known and, accordingly, this is the only thing he can give to others (HD 178). His experience with the prostitute Mary (like Dee's with Marion) also gives witness to a dynamics of separation in which, as Vernon (1973: 8-9) puts it, copulation ceases to be a magic act to become an act of radical acquisition which separates the self from the body and turns the latter into both a commodity and a mere object of need and desire.

Epistemological questions are somehow based on separation, too, not only in their association with knowledge (and the above-mentioned dual systems of formal logic) but also on account of the fact that they establish a breach between the knower and the known. What opens the protagonists' eyes must be, then, an experience oriented towards integration, which is not obliteration of parts, but simultaneous perception of parts and whole - the whole in the part and the part in the whole, as in the Tree of Life. McHale's ontological questions reveal a similar acknowledgement of diversity in unity-several worlds in my world, several selves in my self, etc.-, which recalls, in addition, the defining features of postmodernist fiction: plurivocity, ambiguity, eclecticism, blurring of boundaries (between reality and fiction, history and storytelling, order and chaos, etc).

Dr Dee's house symbolizes itself the integrative dynamics of Vernon's garden. It occupies the site of both Good (the nunnery) and Evil (the brothel) (HD 16-17), and the district where it is set is called after the Clerks' Well, whose water is the regenerative water of life (HD 16). The building is of all times and of none, and in its interior meet different temporal dimensions and different selves which coexist as one, as if the place exerted a centripetal force and everything were attracted to its core. But, apart from the house, there are two other gardens in the novel, gardens which are so in both literal and figurative ways.

When Matthew learns about his father and reflects on his past attitude to him and, especially, to his mother, he realizes that he had never tried to understand anything about those around him and, above all, that he had never "bothered" to love his mother (HD 174). Ready to make a new start, with his life in general and his mother, in particular, he decides to pay her a visit only to find her "'working' in the garden" (HD 175). After listening to Matthew's account, his mother tells him that he was adopted and that she prevented his father from committing sexual abuse on him. With the recognition comes the reconciliation as well as Matthew's personal view of eternity and love (HD 178), in the garden.

As to Dee's anagnorisis, it coincides with a vision of what Dee calls "the world with love" (HD 246), in a chapter entitled, precisely, "The Garden", and which is to be opposed to a previous vision of "the world without love" (HD 205), in a chapter entitled "The City". In this vision of the world without love Dee meets his old master, Ferdinand Griffen, who shows him the new map of London. But the London which this map represents reveals itself in Dee's eyes as a place of death, misery, darkness and separation.

By contrast to the world without love (the London of the map), Dee's vision of the world with love is an altered version of his own garden at Clerkenwell which now appears in the guise of a hortus conclusus In it, all opposites-sweet roses and sharp nettles, 
pleasant lilies and pricking thorns, high vines and low hedges - merge around a tree which Dee describes as "the tree of Our Lord" (HD 254) and which is no other than the Tree of Life itself.

Thus, Dee understands that, obsessed with his search for knowledge, he has had no time to look at the world around him and see it truly. Doing so now, he decides to leave the path of wordly knowledge and seek the original spirit within him as the only way to reach eternity (HD 257). It is with this vision of eternity that the book closes as Matthew's, Dee's and Ackroyd's voices meet in an atemporal dimension where they can all become one and live forever in the realm of the imagination.

According to Vernon (1973: 111), what governs the garden is integration in its true sense, integration that unites itself and its opposite, which is the same as saying that the true sense of the garden unites the garden and the map. This is also the major structural contour of Ackroyd's novel and the key to approach it as a postmodernist work written under the sign of McHale's ontological dominant and yet undeniably constructed around the epistemological quests of its "cognitive heroes". In a sense, many of the questions related to Matthew's and Dee's search for knowledge are left open, questions concerning Dr Dee's "true" identity -a black magician, a scientist, a Christian (HD 93,131, 261), and what else - the buried city of London, Matthew's connection with Dee's homunculus, etc. From another persective, though, Matthew and Dee discover something much more important, which is the redemptive power of love. And as they do so, the text opens to a range of characteristically potsmodernist themes and strategies-self-conciousness, structural games, transworld identity and blurring of boundaries, etc.-- which become dominant in the work and on which I have focused my analysis.

What this ambivalence should teach us is perhaps that postmodernism does not belong to the world of the map but to that of the garden, the realm where there is no place for static exclusiveness and separation. Thus, postmodernist literature can be seen as the materialization of Federman's previsions that "in the fiction of the future, all distinctions between real and imaginary, between the conscious and the subconscious, between the past and the present, between truth and untruth will be abolished" (1975: 8). Postmodernism has progressively done away with all traditional oppositions in a process that affects the materials and devices used to write a novel, as well as the entire enterprise of telling period styles apart -or, more generally, the entire enterprise of literary history-, not to mention the distinction between fictional and "real" worlds. This being so, the literary critic's attitude should not be proprietary and dogmatic but, rather, as open and playful as postmodernism itself is.

We are justified, McHale explains, in supporting a certain account of postmodernism just as long as we refrain from doing so in the mode of objectivity, that is, as long as we do not claim that "our story is 'true', a faithful representation of things as we find them 'out there' in the world . . . but only that our story is interesting to our audience and strategically useful" (1992: 25, italics in the original). If we apply this to the task of interpreting a literary work and, more specifically, to my analysis of The House of Doctor Dee, I can only say that both McHale's and Vernon's insights have proved to be strategically useful to me and that I hope my own insights will be interesting to my "audience", even if they are only one more story. 


\section{Notes}

1. The research carried out for the writing of this paper has been financed by the Spanish Ministry of Education and Science, PB97-1022.

2. An earlier and shorter version of this second part of the article was presented as a contribution to the 21st AEDEAN conference, held in Sevilla, December 1997.

3. The House of Doctor Dee 5. Hereafter the abbreviation HD will be used in parenthetical references.

4. The ontological hesitation of illusion-breaking literature affects not only the work itself -fictional characters and worlds- but also the reader of that particular work, who cannot but get involved in the novel's questioning of the boundary that separates reality and fiction.

\section{Works cited}

Ackroyd, Peter. The House of Doctor Dee. London: Hamish Hamilton, 1993

Eco, Umberto. 1980. The Name of the Rose. Trans. William Weaver. San Diego, New York, London: Harcout Brace Jovanovich, 1983. 1983. Postscript to The Name of the Rose. Trans. William Weaver. San Diego, New

York, London: Harcout Brace Jovanovich, 1984. "Lector in Fabula. Pragmatic Strategy in a Metanarrative Text". The Role of the Reader:

Explorations in the Semiotics of Texts. Bloomington and London: Indiana University Press, 1979. 200-260.

Federman, Raymond. 1975. "Surfiction: Four Propositions in Form of an Introduction", in Surfiction: Fiction Now and Tomorrow. Ed. Raymond Federman. Chicago: Swallow, 1975. 5-15.

Higgins, Dick. A Dialectic of Centuries: Notes Towards a Theory of the New Arts. New York and Barton, VT: Printed Editions, 1978.

Hutcheon, Linda. A Poetics of Postmodernism: History, Theory, Fiction. New York and London: Routledge, 1974.

McHale, Brian. Postmodernist Fiction. New York and London: Methuen, 1987. . Constructing Postmodernism. London: Routledge, 1992.

Vernon, John. The Garden and the Map: Schizophrenia in Twentieth-Century Literature and Culture. Urbana: University of Illinois Press, 1973.

Waugh, Patricia, ed. Postmodernism. A Reader. London and New York: Edward Arnold, 1992. 